\title{
Histopathology of the synovial membrane of peripheral joints in ankylosing spondylitis
}

\author{
P. A. REVELL AND V. MAYSTON \\ From the Bone and Joint Research Unit (ARC), The London Hospital Medical College, London E1 $2 A D$
}

SUMMARY The histological features of the synovial membrane of peripheral joints in ankylosing spondylitis are similar to those seen in rheumatoid arthritis. There is intimal cell hyperplasia, a diffuse lymphocyte and plasma cell infiltrate, and formation of lymphoid follicles. Peroxidaseantiperoxidase staining shows the presence of IgG-, IgA-, and IgM-containing plasma cells in ankylosing spondylitis. The percentage of IgM-containing cells is significantly lower in ankylosing spondylitis than in rheumatoid arthritis.

The histology of the synovial membrane of peripheral joints in ankylosing spondylitis has been examined in a small series of cases by Cruickshank, ${ }^{1}$ Julkunen, ${ }^{2}$ and Wagner ${ }^{3}$ and the appearances found to be basically similar to those of rheumatoid arthritis. Geiler ${ }^{4}$ and Fassbender ${ }^{5}$ also gave descriptions, but did not formally examine a series of biopsies.

Immunohistochemical methods have previously been applied to the rheumatoid synovium by numerous workers, ${ }^{6-17}$ but these methods have not been used in the other arthritides except for occasional cases. $^{9}{ }^{1718}$

We have obtained histological sections of synovial membrane from ankylosing spondylitics and wish to report our findings using routine staining techniques and the peroxidase-antiperoxidase (PAP) immunohistochemical method for the detection of immunoglobulin subclasses in plasma cells present in the synovial membrane. A series of rheumatoid synovial membranes have been examined for comparison. The PAP method enabled accurate identification of the site of immunoglobulin, which is not possible with the fluorescent methods used by previous workers.

\section{Materials and methods}

A series of 14 samples of synovial tissue from ankylosing spondylitis was obtained from the London Hospital or kindly sent by colleagues at other centres. These samples were derived from synovial biopsies at the time of synovectomy or joint replacement. Synovial membrane has also been studied from 14 cases of Accepted for publication 13 November 1981.

Correspondence to Dr P. A. Revell, Bone and Joint Research Unit, The London Hospital Medical College, London E1 2AD. rheumatoid arthritis (all definite or classical except one probable rheumatoid arthritis; ARA criteria ${ }^{19}$ ) obtained at the time of synovectomy, joint replacement, or other surgery at this hospital. The patients with ankylosing spondylitis were aged between 8 and 42 years and the synovial membrane came from 7 hips, 5 knees, and 2 ankles. The rheumatoid arthritis group of patients were aged between 25 and 61 years at the time synovial membrane became available and material was obtained from 9 knees, 3 wrists, 1 finger, and 1 elbow. The duration of clinical symptoms before tissue was taken varied from 6 months to 25 years in the ankylosing spondylitics and 6 months to 20 years in rheumatoid arthritis. Sufficient material was available for immunohistochemical staining in 10 cases of ankylosing spondylitis. Twelve of the rheumatoid synovial membranes were selected at random before examination by routine light microscopy, and these were stained by immunohistochemical methods for comparison with the spondylitic synovial membranes.

\section{HISTOLOGICAL PROCESSING AND STAINING} METHODS

All the rheumatoid synovial membranes and those from ankylosing spondylitics in our own hospital group were fixed in $10 \%$ formol saline. Inquiries of other laboratories which had submitted material confirmed that these had also been fixed in this way with the exception of 3 cases in which no details of fixation could be obtained. All the samples were processed on automatic tissue processors, embedded in paraffin wax, and sectioned at $5 \mu \mathrm{m}$ thickness. Sections were stained by the haematoxylin and eosin (HE), Martius scarlet blue (MSB), Highman's Congo red (CR), 
Unna-Pappenheim (UP) and Perl's Prussian blue (iron) techniques.

Further sections were stained by the peroxidaseantiperoxidase (PAP) technique to demonstrate the presence of IgG, IgA, and IgM immunoglobulin subclasses. Rabbit antihuman IgG, IgA, and IgM, normal swine, swine antirabbit, and peroxidase sera were used. Reagents were obtained from Dakopatts (Mercia Brocades Ltd).

Optimal dilutions of the antisera were found to be $1: 800$ for rabbit anti-IgG, 1:400 for rabbit anti-IgA and IgM, and 1:20 for swine antirabbit antiserum in preliminary experiments. The specificity of the antisera was checked against cases of plasma cell tumours of known specificity in paraffin sections (IgG plasmacytoma, IgA myeloma, IgM lymphoplasmacytic malignant lymphoma). Endogenous peroxidase was inhibited by treatment of a series of sections from each biopsy with freshly prepared $0.5 \% \mathrm{H}_{2} \mathrm{O}_{2}$ in methanol for 30 minutes. All sections were pretreated with $0 \cdot 1 \%$ pancreatic trypsin (type II; Sigma,

Table 1 Histological features of the synovium in ankylosing spondylitis

\begin{tabular}{lllll}
\hline & 0 & + & ++ & +++ \\
\hline Synovial lining cell hyperplasia & 2 & 4 & 7 & 1 \\
Surface fibrin & 5 & 3 & 5 & 1 \\
Incorporated fibrin & 9 & 2 & 3 & 0 \\
Iron deposition & 6 & 5 & 3 & 0 \\
Diffuse lymphoid cells & 0 & 7 & 5 & 2 \\
Lymphoid cell aggregates & 6 & 2 & 4 & 2 \\
Fibrosis & 8 & 3 & 3 & 0 \\
Perivascular fibrosis & 8 & 2 & 4 & 0 \\
Increased vascularity & 1 & 4 & 9 & 0 \\
Perivascular lymphocytes & 2 & 6 & 4 & 2 \\
\hline
\end{tabular}

Histological features: $0=$ absent,$+=$ mild, $++=$ moderate,$+++=$ marked.
London) in $0 \cdot 1 \% \mathrm{CaCl}_{2}(\mathrm{pH} 7 \cdot 8)$ for 20 minutes. The peroxidase reaction was developed with $3,3^{\prime}$ diaminobenzidine tetrahydrochloride (DAB) $(\mathrm{BDH}$ Chemicals). Positive control material was used throughout and was provided by paraffin-processed tonsil.

\section{EXAMINATION OF HISTOLOGICAL SECTIONS}

The histological appearances were described for each case and the presence of certain histological features scored on a 0 to +++ basis, these 4 categories representing whether the features were absent, mild, moderate, or marked. The number of plasma cells containing a particular immunoglobulin subtype was measured by counting 500 cells in the subintimal cellular infiltrate. Exactly the same area was chosen in adjacent serial sections and the exact number of fields recorded and used to count IgG, IgA, and IgM. In this way errors due to differences in sampling within a section were found to be kept to a minimum, and reproducible results between the 2 observers were obtained, with errors of less than $10 \%$. Only cells that were distinguishable as plasma cells were counted in sections which had been treated by hydrogen peroxide to abolish staining of endogenous peroxidase.

\section{Results}

Histological examination of the synovial membrane in ankylosing spondylitis showed appearances which were similar to those seen in rheumatoid arthritis. The results of a semiquantitative assessment of the main histological features are shown in Table 1.

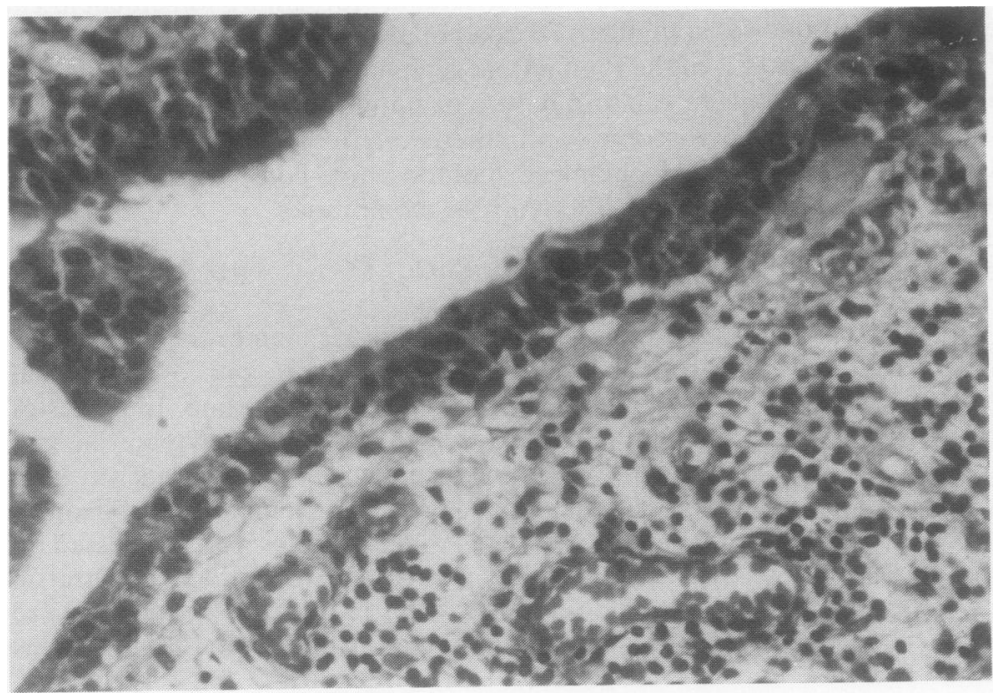

Fig. 1 Synovial membrane in ankylosing spondylitis, showing marked intimal cell hyperplasia and diffuse lymphoid cell infiltrate. (Haematoxylin-eosin, $\times$ 568). 
There was synovial lining cell (intimal cell) hyperplasia in nearly all cases, and this was moderate or marked in the majority of them (Fig. 1). The duration of involvement of the affected joint was 8 months and 15 years respectively in the 2 cases not showing intimal cell hyperplasia. Surface fibrin was seen frequently (Fig. 2), and fibrin was incorporated into the subsynovial tissue in some synovial membranes. A lymphocytic infiltrate was present in all cases and lymphoid follicles (aggregates) were present in just over half the cases (Fig. 3). Plasma cells were a dominant feature of the diffuse lymphoid cell infiltrate in nearly every case (Fig. 4). Small amounts of iron were present in cells in the synovial connective tissue in some biopsies, and this was not a marked feature of any of them. There was an increase in the vascularity of the subsynovial tissues in all but one case. The vessels were frequently surrounded by cuffs of lymphocytes, but there was no true vasculitis. Fibrosis was frequently seen and had a perivascular distribution (Fig. 5) as well as diffuse pattern. Incorporation of small fragments of cartilage and bone debris from the joint surface was seen in one case of a 33-year-old male with hip involvement for 21 years. There was otherwise no evidence of incorporation of detritic material.
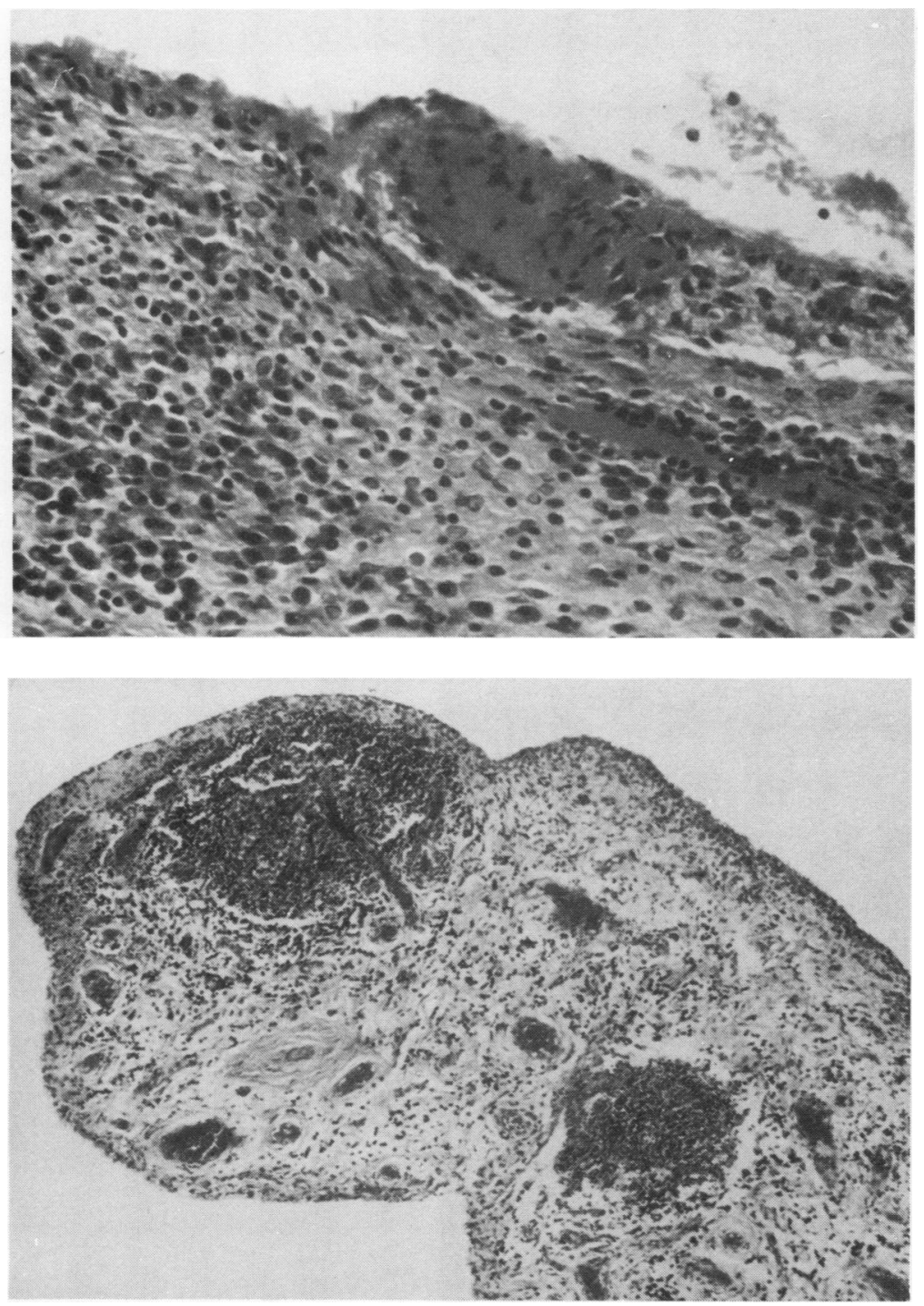

Fig. 2 Synovial membrane in ankylosing spondylitis, showing moderate intimal cell hyperplasia, fibrin deposition, and lymphocyte and plasma cell infiltrate.

(Haematoxylin-eosin, $\times 568$ ).

Fig. 3 Synovial membrane in ankylosing spondylitis, showing lymphoid follicles and increased vascularity. (Haematoxylin-eosin, $\times 142$ ). 


\section{Revell, Mayston}

The presence of particular histological features could not be related to the duration of disease in ankylosing spondylitis. Thus, for example, those cases of ankylosing spondylitis without lymphoid follicles had histories of involvement for 6 months to 25 years in the affected joint, while in those with lymphoid follicles the history varied between 18 months and 15 years. Similarly, perivascular fibrosis was absent from cases having involvement for 6 months to 25 years and yet was present in those with disease present for 6 months to 20 years.

A comparison of ankylosing spondylitis and rheumatoid arthritis showed that surface fibrin was present less often and was less marked as a feature in the former condition (Fig. 6). Lymphoid follicles were also less frequent in ankylosing spondylitis.

There was otherwise a close similarity between the histological features of the synovium in the 2 conditions.

\section{IMMUNOHISTOCHEMICALSTUDIES}

Staining of trypsinised paraffin sections for immunoglobulin subclasses showed the presence of IgG-, IgM-, and IgA-containing plasma cells in the cellular infiltrate present in the synovium of both

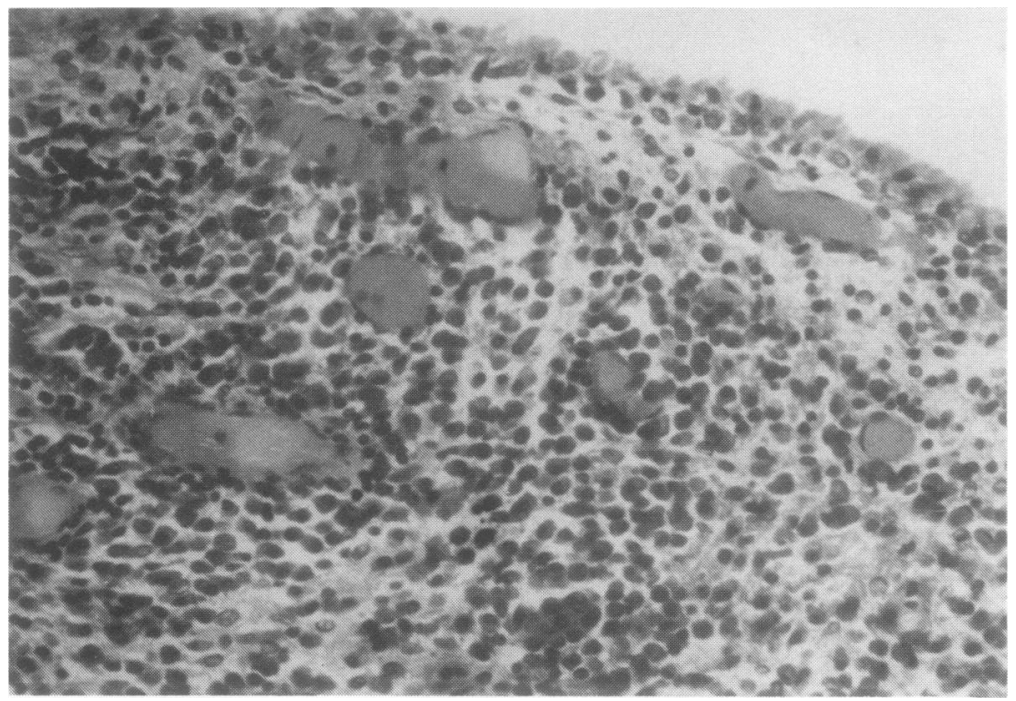

Fig. 4 Synovial membrane in ankylosing spondylitis, showing predominance of plasma cells in the cellular infiltrate. There is mild intimal cell hyperplasia and an increase in thin-walled vessels. (Haematoxylin-eosin, $\times 568$ ).

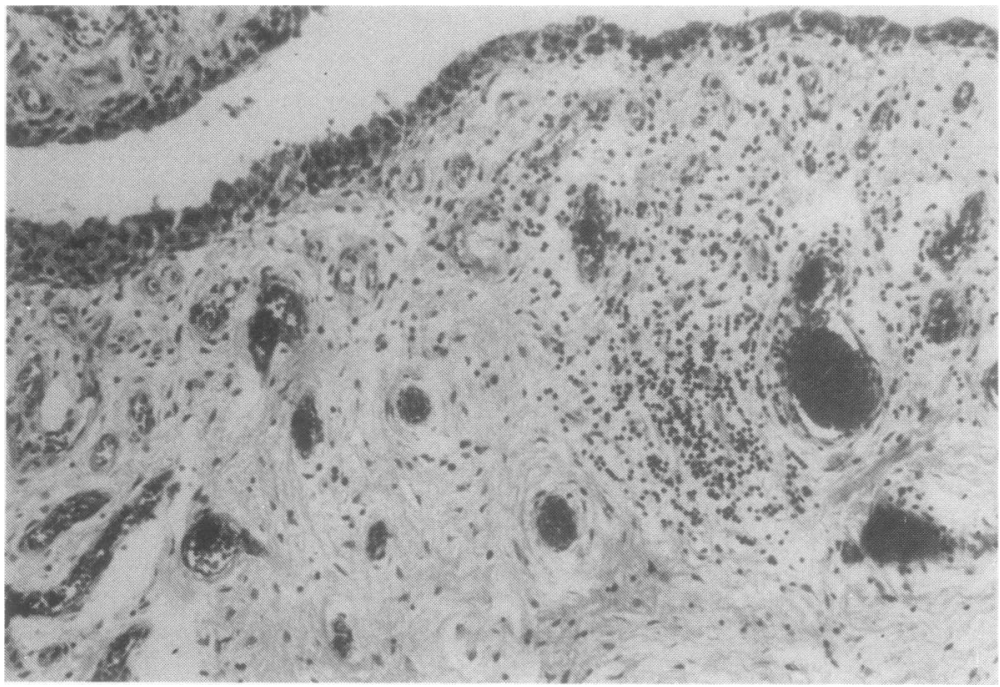

Fig. 5 Synovial membrane in ankylosing spondylitis, showing increase in numbers of vessels with perivascular fibrosis. There is marked intimal cell hyperplasia. (Haematoxylin-eosin, $\times 284$ ). 

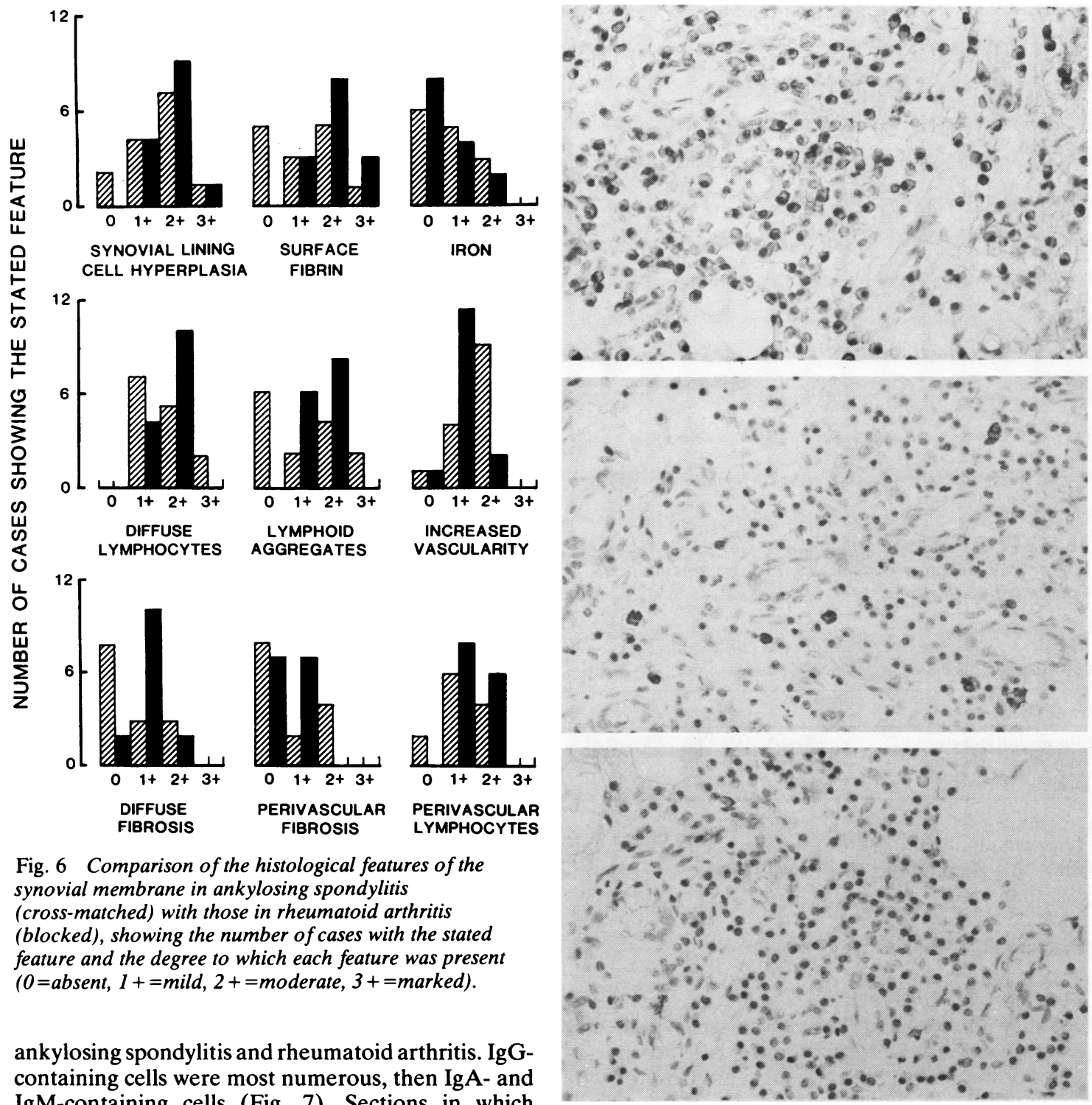

Fig. 6 Comparison of the histological features of the synovial membrane in ankylosing spondylitis (cross-matched) with those in rheumatoid arthritis (blocked), showing the number of cases with the stated feature and the degree to which each feature was present $(0=$ absent, $1+=$ mild, $2+=$ moderate, $3+=$ marked $)$.

ankylosing spondylitis and rheumatoid arthritis. IgGcontaining cells were most numerous, then $\operatorname{IgA}$ - and IgM-containing cells (Fig. 7). Sections in which endogenous peroxidase had not been abolished with hydrogen peroxide treatment also showed reaction product in macrophages. Occasional macrophages showed the presence of peroxidase after hydrogen peroxide treatment, and these were taken to be cells which contained phagocytosed immunoglobulin. They were clearly distinguishable from plasma cells on morphological grounds.

The percentages of plasma cells containing different subtypes of immunoglobulin were measured by counting 500 cells under high-power magnification in exactly the same areas of adjacent serial sections. The results are shown in Fig. 8. The ranges for

Fig. 7 The same area in adjacent sections of synovial membrane from ankylosing spondylitis stained for different immunoglobulins: (upper) IgG, (middle) IgA, (lower) IgM. Positively staining cells show dark grey or black cytoplasm negative cells are pale grey.

(Peroxidase-antiperoxidase, $\times 486)$.

the values obtained for the different immunoglobulin subclasses in rheumatoid arthritis and ankylosing spondylitis are shown in Table 2 . There was statistically no significant difference between the percentages of plasma cells containing IgG or IgA in the 2 conditions, but the level of IgM-containing plasma 


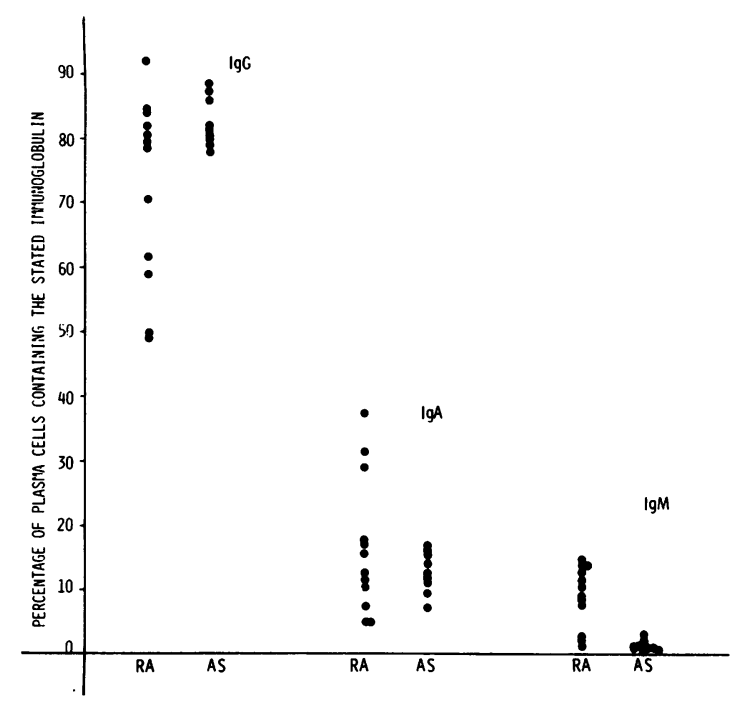

Fig. 8 Percentages of cells staining for $\operatorname{IgG}, \operatorname{Ig} A$, and $\operatorname{Ig} M$ in the synovial membrane in ankylosing spondylitis and rheumatoid arthritis.

Table 2 Percentage of plasma cells containing immunoglobulins of different subclasses

\begin{tabular}{llll}
\hline & $I g G$ & $I g M$ & $I g A$ \\
\hline Rheumatoid arthritis & $49 \cdot 2-92 \cdot 2$ & $1 \cdot 4-14 \cdot 6$ & $5 \cdot 4-37 \cdot 6$ \\
Ankylosing spondylitis & $78 \cdot 6-88 \cdot 2$ & $0 \cdot 6-3 \cdot 0$ & $7 \cdot 4-16 \cdot 8$ \\
(Mann-Whitney U test) & NS & $\mathrm{p}<0 \cdot 002$ & NS \\
\hline
\end{tabular}

cells was significantly lower in ankylosing spondylitis than in rheumatoid arthritis (Table 2) (MannWhitney U test, $\mathrm{p}<0.002$ ).

\section{Discussion}

Conventional histological examination and semiquantitative scoring of the extent to which particular features were present has shown that the appearances of the synovial membrane in ankylosing spondylitis are closely similar to those seen in rheumatoid arthritis. This finding is in agreement with those of previous authors. Cruickshank ${ }^{1}$ examined the peripheral joints of 8 ankylosing spondylitics. Although the appearances were similar to those of rheumatoid arthritis, there was a proliferation of small arteries and arterioles which was thought to be related to the use of radiotherapy in the management of the disease. Vascularisation of the synovial membrane was noted in only 6 out of 17 synovial biopsies in ankylosing spondylitis by Wagner. ${ }^{3}$ When a comparison of the frequency of increased vascularity was made in the present study, the results for rheumatoid arthritis and ankylosing spondylitis were similar, although the changes were scored as mild in the majority of the former and moderate for most of the latter. Although there is increased vascularity in the synovial membrane of ankylosing spondylitis, this is not a helpful feature in the differentiation from rheumatoid arthritis. None of the patients in the present series had received radiotherapy to the affected joint, so that this is not an explanation for the increased vascularity.

Small amounts of iron were present in some biopsies, though this was not a marked feature of any of them, contrary to the description of Cruickshank. ${ }^{1}$

Fibrosis of the synovial tissues has been described as a marked feature in ankylosing spondylitis by Cruickshank $^{1}$ and Fassbender. ${ }^{5}$ Fibrosis was present more often in rheumatoid arthritis in the present study, but was a pronounced feature as often in the 2 diseases. The inflammatory cell infiltrate in ankylosing spondylitis was said to be less intense by Wagner ${ }^{3}$ and Fassbender, ${ }^{5}$ though the present results fail to show this and are in agreement with those of Cruickshank ${ }^{1}$ and Julkunen, ${ }^{2}$ both of whom found a well developed lymphoid cell infiltrate. The histological features in 393 specimens of synovial membrane from various disease categories have been recently examined systematically by Cooper et al. ${ }^{20}$ There were 47 cases of possible or probable rheumatoid arthritis, 127 of definite or classical rheumatoid arthritis, and 17 of ankylosing spondylitis. Fibroblastic proliferation, intimal cell hypertrophy, diffuse lymphocyte and histiocyte infiltration, and fibrin were less marked in ankylosing spondylitis than in definite rheumatoid arthritis, and there were more haemorrhages and thromboses of blood vessels in the former. When comparison was made between ankylosing spondylitis and possible or probable rheumatoid arthritis, however, decreased intimal cell hypertrophy and fibroblastic proliferation were the only differences found. These results are concerned not with the degree to which a feature was present in an individual but with the incidence of the feature within the groups as a whole. We have not found intimal cell hypertrophy, as distinct from hyperplasia, easy to evaluate with any degree of confidence and omitted it from our assessment. Our results are, however, in keeping with those of Cooper et al. ${ }^{20}$ with respect to the degree of diffuse lymphoid cell infiltrate and the amount of fibrin and fibroblastic proliferation in ankylosing spondylitis.

The synovial membrane in rheumatoid arthritis has been studied many times in the past. A recent systematic analysis by Goldenberg and Cohen ${ }^{21}$ showed that the presence of lymphoid follicles, marked diffuse mononuclear cell infiltration, and marked synovial lining cell hyperplasia were virtually diagnostic in distinguishing rheumatoid synovial 
membrane from that of systemic lupus erythematosus, degenerative joint disease, acute bacterial arthritis, gout, and pseudogout. These 3 features were, however, a feature of nearly all the present series of ankylosing spondylitis cases and certainly should not be regarded as specific for rheumatoid arthritis.

The presence of numerous plasma cells in the synovial membrane in ankylosing spondylitis has been well described previously ${ }^{1-3}$ and is confirmed in the present study. The question arises as to the nature of the immunoglobulin being produced by these plasma cells. There are a large number of studies of the presence and distribution of rheumatoid factor in rheumatoid synovial membrane..$^{6-1012-14}$ The presence of rheumatoid factor activity was not investigated in the present study because frozen sections or appropriately fixed synovial membrane, as used in the techniques described by Sainte Marie ${ }^{22}$ or Ball et al. ${ }^{23}$ have not been available. A small number of suitably fixed biopsies in seronegative arthritides, including ankylosing spondylitis, are being studied separately for the presence of rheumatoid factor.

The presence of IgG and IgM in synovial membrane has been described ${ }^{81316}$ and the synthesis of IgG by rheumatoid synovial membrane in vivo has been established. ${ }^{23}$ Both Fish et al. ${ }^{8}$ and Mestecky and Miller ${ }^{16}$ specifically stated that $\operatorname{IgA}$ was absent from rheumatoid synovial membrane. All of these studies have relied on immunofluorescent methods and have the disadvantage that accurate localisation of the immunoglobulin was not possible or not attempted.

The present investigation shows that the majority of plasma cells in the synovial membrane of rheumatoid arthritis and ankylosing spondylitis contained IgG immunoglobulin, a result similar to that of Munthe and Natvig ${ }^{17}$ for rheumatoid disease. These authors found IgA-staining plasma cells which exceeded IgM-containing cells in some cases, and moderate amounts of $\operatorname{IgA}$ were present in synovial fluid in rheumatoid arthritis according to Male et al. ${ }^{11}$ A high proportion of IgA-containing plasma cells was confirmed in our study in both rheumatoid arthritis and ankylosing spondylitis, although there was no difference between the 2 diseases with respect to the percentage of positively staining cells. The percentage of IgM-containing plasma cells was significantly lower in ankylosing spondylitis compared with rheumatoid arthritis. Cracchiolo and Barnet ${ }^{25}$ demonstrated the presence of $\operatorname{IgG}, \operatorname{IgA}$, and $\operatorname{IgM}$ in the synovial fluid of rheumatoid arthritis and that the levels of these immunoglobulins decreased after synovectomy, suggesting local synthesis of all 3 immunoglobulin subclasses. We have shown that the percentage of IgM-containing plasma cells was significantly lower in ankylosing spondylitis than in rheumatoid arthritis. The majority of rheumatoid synovial membranes showed levels ranging from 8 to $14.6 \%$, and only 3 cases were below this level at $1 \cdot 8$, $1 \cdot 4$, and $2 \cdot 6 \%$. All 3 were women with rheumatoid arthritis of 12 to 20 years' duration. It seems likely that the higher levels of IgM-containing cells are a reflection of the production of IgM rheumatoid factor by the inflamed synovial membrane in rheumatoid arthritis. If the synovial membrane is a source of immunoglobulin production which contributes significantly to serum levels, then low levels of IgM-producing plasma cells in the synovial membrane of ankylosing spondylitis are to be expected.

IgM-containing plasma cells were most numerous in tissues of seropositive rheumatoid arthritis and were only rarely detected in patients with seronegative rheumatoid arthritis in the study of Munthe and Natvig. ${ }^{17}$ The case in the present series categorised as probably rheumatoid arthritis was seronegative but showed IgM production in $11.4 \%$ of plasma cells. Fyrand et al. ${ }^{18}$ found that only $7 \%$ of synovial membranes in psoriatic arthritis showed the presence of IgM in mononuclear cells, using an immunofluoresent technique. Definite identification of the cells as plasma cells was not possible using this method.

It is proposed to study further cases of seronegative arthropathy such as Reiter's/syndrome and psoriatic arthropathy as well as seronegative cases of rheumatoid arthritis with respect both to the levels of IgM-containing plasma cells and to the presence of rheumatoid factor.

The authors wish to thank the Arthritis and Rheumatism Council for financial support. We are grateful to Professor H. L. F. Currey and Drs R. François, J. P. Halsey, J. V. Lever, K. Mahmood, A. I. D. Prentice, J. P. O'Sullivan, J. C. Valentine, S. P. B. Way, and D. B. Yates, who have helped by providing biopsy material for this study.

\section{References}

${ }^{1}$ Cruickshank B. Histopathology of diarthrodial joints in ankylosing spondylitis. Ann Rheum Dis 1951; 10: 393-404.

2 Julkunen K. Synovial inflammatory cell reaction in chronic arthritis. Acta Rheumatol Scand 1966; 12: 188-96.

3 Wagner T. The microscopic appearance of synovial membranes in peripheral joints in ankylosing spondylitis. Reumatologia 1970; 8: 209-15.

- Geiler G. Die Spondylarthritis ankylopoietica auf pathologisch-anatomischer Sicht. Dtsch Med Wochenschr 1969; 94: $185-8$

5 Fassbender H G. Pathology of Rheumatic Diseases. Heidelberg, New York: Springer 1975: chapter 8, 221-44.

6 Bonomo L, Tursi A, Gilliardi U. Distribution of the anti-gamma globulin factors in the synovial membrane and other tissues in various diseases. Ann Rheum Dis 1968; 27: $122-9$.

7 Bonomo L, Tursi A, Trizio D, Gilliardi U, Dammacco F. Immune complexes in rheumatoid synovitis; a mixed staining immunofluorescence study. Immunology 1970; 18: 557-63. 
${ }^{8}$ Fish A J, Michael A F, Gewurz H, Good R A Immunopathologic changes in rheumatoid arthritis synovium. Arthritis Rheum 1966; 9: 267-80.

จ Friis J. Immunohistochemical demonstration of rheumatoid factor (RF) in alcohol-fixed synovial tissue from patients with rheumatoid arthritis (RA). Acta Pathol Microbiol Scand 1969; 75: 71-84.

${ }^{10}$ Kaplan M H. The site of formation of rheumatoid factor. Arthritis Rheum 1963; 6: 475-80.

${ }^{11}$ Male D, Roitt I M, Hay F C. Analysis of immune complexes in synovial effusions of patients with rheumatoid arthritis. Clin Exp Immunol 1980; 39: 297-306.

${ }_{12}$ McCormick J N. An immunofluorescence study of rheumatoid factor. Ann Rheum Dis 1963; 22: 1-10.

${ }^{13}$ Mellors R C, Heimer R, Corcos J, Korngold L. Cellular origin of rheumatoid factor. $J$ Exp Med 1959; 110: 875-86.

${ }_{14}$ Mellors R C, Nowoslowski A, Korngold L. Rheumatoid arthritis and the cellular origin of rheumatoid factors. Am J Pathol 1961; 39: 553-46.

1s Mellors R C, Nowoslawski A, Korngold L, Sergson B L. Rheumatoid factor and the pathogenesis of rheumatoid arthritis. J Exp Med 1961; 113: 475-84.

${ }^{16}$ Mestecky J, Miller E J. Presence of antibodies specific to cartilage-type collagen in rheumatoid synovial tissue. Clin Exp Immunol 1975; 22: 453-6.

${ }^{17}$ Munthe E, Natvig J B. Immunoglobulin classes, subclasses and complexes of IgG rheumatoid factor in rheumatoid plasma cells. Clin Exp Immunol 1972; 12: 55-70.

${ }^{18}$ Fyrand $\mathrm{O}$, Mellbye $\mathrm{O} \mathrm{J}$, Natvig $\mathrm{J}$ B. Immunofluorescence studies for immunoglobulins and complement $\mathrm{C} 3$ in synovial joint membranes in psoriatic arthritis. Clin Exp Immunol 1977; 29: 422-7.

19 Ropes M W, Bennet G A, Cobb S, Jacox R, Jessar R A. Diagnostic criteria for rheumatoid arthritis. Ann Rheum Dis 1959; 18: 49-53.

${ }^{20}$ Cooper N S, Soren A, McEwen C, Rosenberger J L. Diagnostic specificity of synovial lesions. Hum Pathol 1981; 12: 314-28.

21 Goldenberg D L, Cohen A S. Synovial membrane histopathology in the differential diagnosis of rheumatoid arthritis, gout, pseudogout, systemic lupus erythematosus, infectious arthritis and degenerative joint disease. Medicine (Baltimore) 1978; 57: 239-52.

${ }^{22}$ Sainte-Marie G. A paraffin embedding technique for studies employing immunofluorescence. J Histochem Cytochem 1962; 10: $250-6$.

${ }^{23}$ Ball J, Bahgat N, Taylor G. Effect of aldehyde fixation on cellular rheumatoid factor and certain tissue antigens. $J$ Histochem Cytochem 1964; 12: 737-9.

${ }^{24}$ Sliwinski $\mathrm{A}$ J, Zvaifler $\mathrm{N}$ J. In vivo synthesis of IgG by rheumatoid synovium. J Lab Clin Med 1970; 76: 304-10.

${ }^{25}$ Cracchiolo A, Barnett E U. Immunologic changes in synovial fluid following synovectomy of the knee for rheumatoid arthritis. J Bone Joint Surg 1969; 51A: 475-86. 